\title{
Perancangan Sistem Perangkap Hama Tanaman Petani Otomatis Menggunakan Modul Mikrokontroler Arduino
}

\author{
Rahmat Tampune Bangun ${ }^{*}$, Hasanul Fahmi \\ ${ }^{1,2}$ STMIK Pelita Nusantara \\ Jl. Iskandar Muda No. 1 Medan 20154 Indonesia \\ Corresponding author‘s e-mail: lord.bangun@gmail.com
}

\begin{abstract}
Abstrak - Suatu hewan juga dapat disebut hama jika menyebabkan kerusakan pada ekosistem alami atau menjadi agen penyebaran penyakit dalam habitat manusia. Hama yang dimaksud adalah hewan sejenis tikus bertujuan membuat perangkap menggunakan sensor berat load cell dengan mikrokontroler modul Mikrokontroler Arduino. Ruang lingkup permasalahan dalam penelitian ini adalah perladangan jagung dan persawahan padi di Kecamatan Mardingding Kabupaten Karo untuk keperluan pengujian digunakan 3 kali percobaan dari masing-masing perladangan jagung dan persawahan padi. Variabel dibatasi hanya untuk binatang seukuran tikus. Tujuan dari penelitian ini adalah membangun sebuah alat perangkap hama tanaman dengan menggunakan modul micro controller Arduino uno yang bisa memberikan kemudahan dalam menangkap hama secara efisien. Petani tidak perlu lagi untuk mengontrol dalam jangka waktu tertentu. sehingga dapat menghemat waktu dan energi untuk melakukan pekerjaan lainnya. Aplikasi dibangun menggunakan bahasa pemrograman yang digunakan adalah bahasa $\mathrm{C}$ dan IDE Arduino dengan pemberitahuan kepada petani hanya melalui pesan singkat melalui handphone.
\end{abstract}

Kata kunci: Teknologi, Hama, Perangkap, Arduino Uno, Sensor

Abstract - An animal can also be called a pest if it causes damage to natural ecosystems or acts as an agent for spreading disease in human habitats. The pest in question is a mouse-like animal that aims to make a trap using a load cell weight sensor with an Arduino microcontroller module. The scope of the problem in this research is the cultivation of maize and paddy fields in Mardingding District, Karo Regency. For testing purposes, 3 trials are used, respectively, corn and rice fields. The variable is limited to animals the size of a mouse. The purpose of this research is to build a plant pest trapping device using the Arduino uno micro controller module which can make it easier to catch pests efficiently. Farmers no longer need to control within a certain period of time. so it can save time and energy to do other jobs. The application is built using the programming language used is the Clanguage and the Arduino IDE with notification to farmers only via short messages via cellphones.

Keywords: Technology, Pests, Traps, Arduino Uno, Sensor

\section{Pendahuluan}

Hama adalah gangguan bagi petani karena bisa merusak tanaman hingga terjadi gagal panen. Jika menggunakan cara manual dengan dengan menebar racun atau membuat perangkap konvensional dengan kayu dan jaring tentu akan sangat memerlukan energi dan waktu yang mana hama masih memungkinkan untuk lolos. Karena itu diperlukan suatu solusi dalam pembasmian hama. Salah satu solusinya adalah menggunakan perangkap yang dapat menangkap hama dengan memastikan hama tidak akan lepas dan dapat digunakan dalam jangka waktu yang panjang.

Mikrokontroler adalah sebuah chip yang berfungsi sebagai pengontrol rangkaian elektronik dan umunya dapat menyimpan program didalamnya[1]. Mikrokontroler umumnya terdiri dari CPU (Central Processing Unit), memori, I/O tertentu dan unit pendukung seperti Analog-to-Digital Converter (ADC) yang sudah terintegrasi di dalamnya. Kelebihan utama dari mikrokontroler ialah tersedianya RAM dan peralatan I/O pendukung sehingga ukuran board mikrokontroler menjadi sangat ringkas. Mikrokontroler MCS51 ialah mikrokomputer CMOS 8 bit dengan 4 KB Flash PEROM (Programmable and Erasable Only Memory) yang dapat dihapus dan ditulisi sebanyak 1000 kali. Mikrokontroler ini diproduksi dengan menggunakan teknologi high density non-volatile memory. Flash PEROM on-chip tersebut memungkinkan memori program untuk diprogram ulang dalam sistem (in-system programming) atau dengan menggunakan programmer non-volatile memory konvensional. Kombinasi CPU 8 bit serba guna dan Flash PEROM, menjadikan mikrokontroler MCS51 menjadi microcomputer handal yang fleksibel [2].

Arduino adalah kit elektronik atau papan rangkaian elektronik open source yang di dalamnya terdapat komponen utama yaitu sebuah chip mikrokontroler dengan jenis AVR dari perusahaan Atmel. Mikrokontroler itu sendiri adalah chip atau IC (integrated circuit) yang bisa diprogram menggunakan komputer. Tujuan 
menanamkan program pada mikrokontroler adalah agar rangkaian elektronik dapat membaca input, memproses input tersebut dan kemudian menghasilkan output sesuai yang diinginkan. Jadi mikrokontroler bertugas sebagai 'otak' yang mengendalikan input, proses dan output sebuah rangkaian elektronik [3].

Load cell adalah komponen utama pada sistem timbangan digital. Tingkat keakurasian timbangan bergantung dari jenis load cell yang dipakai. Sensor load cell apabila diberi beban pada inti besi maka nilai resistansi di strain gauge-nya akan berubah yang dikeluarkan melalui tiga buah kabel. Dua kabel sebagai eksitasi dan satu kabelnya lagi sebagai sinyal keluaran ke kontrolnya [4]. Sebuah load cell terdiri dari konduktor, strain gauge, dan wheatstone bridge.

Arduino Development Environment adalah sebuah perangkat lunak yang memudahkan kita mengembangkan aplikasi mikrokontroler mulai dari menuliskan source program, kompilasi, upload hasil kompilasi, dan uji coba secara terminal serial. Arduino [5] Development Environment terdiri dari editor teks untuk menulis kode, sebuah area pesan, sebuah konsol, sebuah toolbar dengan tombol-tombol untuk fungsi yang umum dan beberapa menu. Arduino Development Environmentterhubung ke arduino board untuk mengupload program dan juga untuk berkomunikasi dengan arduino board.

Pada perangkap yang akan diciptakan, terdapat beberapa kelebihan disbanding menebar racun ataupun memasang perangkap konvensional yaitu memberi informasi ada atau tidaknya hama yang masuk dan memastikan hama tetap pada tempatnya. Perangkap ini dirancang agar dapat memberikan informasi mengenai berhasil atau tidaknya hewan masuk kedalam perangkap yang mana hama akan melewati beberapa sensor sebagai pendeteksi situasi. Saat perangkap sedang bekerja dan menangkap hasil, maka informasi akan dikirim dari modul arduino ke handphone petani, sehingga petani tahu bahwasannya perangkap berhasil bekerja, dan petani pun tahu berapa jumlah hasil tangkapan dengan mudah [6].

\section{Tinjauan Pustaka}

\subsection{Pernyataan IF}

Pernyataan IF adalah salah satu pernyataan penyeleksian yang memungkinkan kita memanipulasi aliran jalannya program berdasarkan conditional expression. Hal ini dapat memungkinkan kita membuat program yang berjalan secara fleksibel sesuai keadaan dari pengguna dan mesin. Penyeleksian if adalah pernyataan penyeleksian yang mencari kebenaran dari conditional expression yang disebutkan [7]. Eonditional expression harus berupa bilangan Boolean atau operasi yang menghasilkan bilangan Boolean dan menyatakan benar atau salah atas expression tersebut.

\subsection{Arduino Uno}

Arduino Uno adalah salah satu development kit mikrokontroler yang berbasis pada ATmega28. Arduino Uno merupakan salah satu board dari family Arduino. Ada beberapa macam arduino bard seperti Arduino Nano, Arduino Pro Mini, Arduino Mega, Arduino Yun, dll. Namun yang paling populer adalah Arduino Uno. Arduino Uno R3 adalah seri terakhir dan terbaru dari seri Arduino USB. Arduino Uno memiliki 14 pin digital (6 pin dapat digunakan sebagai output PWM), 6 input analog, sebuah $16 \mathrm{MHz}$ osilator kristal, sebuah koneksi USB, sebuah konektor sumber tegangan, sebuah header ICSP, dan sebuah tombol reset. Arduino Uno memuat segala hal yang dibutuhkan untuk mendukung sebuah mikrokontroler. Hanya dengan menhubungkannya ke sebuah komputer melalui USB atau memberikan tegangan DC dari baterai atau adaptor AC ke DC sudah dapat membuanya bekerja [8]. Arduino Uno menggunakan ATmega16U 2 yang diprogram sebagai USB-to-serial converter untuk komunikasi serial ke komputer melalui port USB.

\section{Metode Penelitian}

Flowchart proses dimulai ketika objek memulai masuk ke dalam perangkap, jika berat obejk mencukupi parameter yang telah diatur pada program maka motor dc akan bergerak menggeser dinding perangkap kearah pengampung perangkap, setelah mesin selesai bergerak, modul Sim800L akan mengirim pesan ke pengguna. 


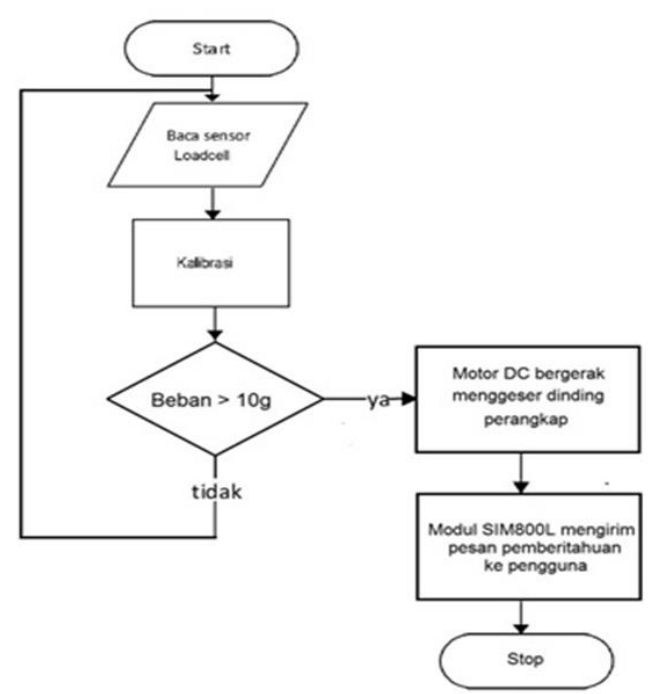

Gambar 1. Flowchart Perancangan Perangkap Hewan Otomatis Menggunakan Mikrokontroler Arduino

\section{Hasil dan Pembahasan}

Proteus 8 adalah sebuah software simulasi versi ke 8 dari proteus yang mengkombinasikan program ISIS (Intelligent Schematic Input System) untuk membuat sebuah skematik rangkaian elektronika dan program ARES untuk membuat sebuah layout PCB. Software ini bagus untuk mempelajari dasar-dasar elektronika dan sekaligus dapat melakukan simulasi elektronika.

Fitur-fitur dari PROTEUS adalah sebagai berikut :

1. Memiliki kemampuan untuk mensimulasikan hasil rancangan baik digital maupun analog maupun gabungan keduanya,

2. Mendukung simulasi yang menarik dan simulasi secara grafis

3. Mendukung simulasi berbagai jenis microcontroller seperti PIC, 8051 series.

4. Memiliki model-model peripheral yang interactive seperti LED, tampilan LCD, RS232, dan berbagai jenis library lainnya.

5. Mendukung instrument-instrument virtual seperti voltmeter, amperemeter, oscciloscope, logic analyser, dll,

6. Memiliki kemampuan menampilkan berbagi jenis analisis secara grafis seperti transient, frekuensi, noise, distorsi, AC dan DC, dll.

7. Mendukung berbagai jenis komponen-komponen analog, Mendukung open architecture sehingga kita bisa memasukkan program seperti $\mathrm{C}++$ untuk keperluan simulasi,

8. Mendukung pembuatan PCB yang di-update secara langsung dari program ISIS ke program pembuat PCB-ARES.

Proteus ISIS merupakan program terintegrasi dengan proteus yang menjadi program utama pada software proteus. ISIS dirancang untuk membuat sebuah skematik rangkaian elektronika dan dapat menyimulasikan rangkaian dengan memberikan sebuah program ke dalam sebuah mikroprosesor. Software proteus ISIS dapat dilihat pada gambar 2 . 


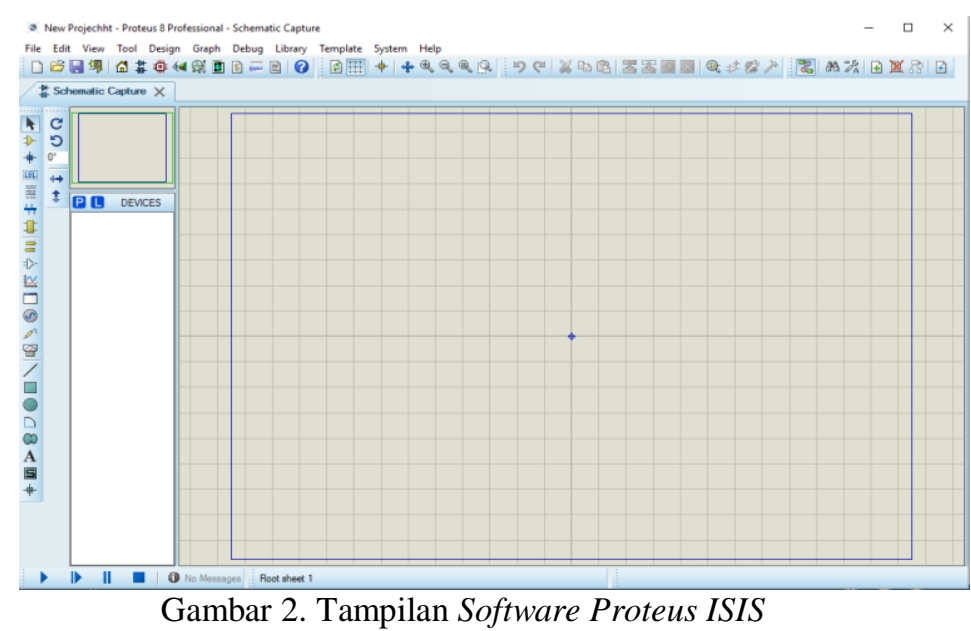

Proteus ARES merupakan tempat untuk membuat layout PCB berdasarkan skematik rangkaian elektronika yang telah dibuat di ISIS. Software Proteus ARES dapat dilihat pada gambar 3.

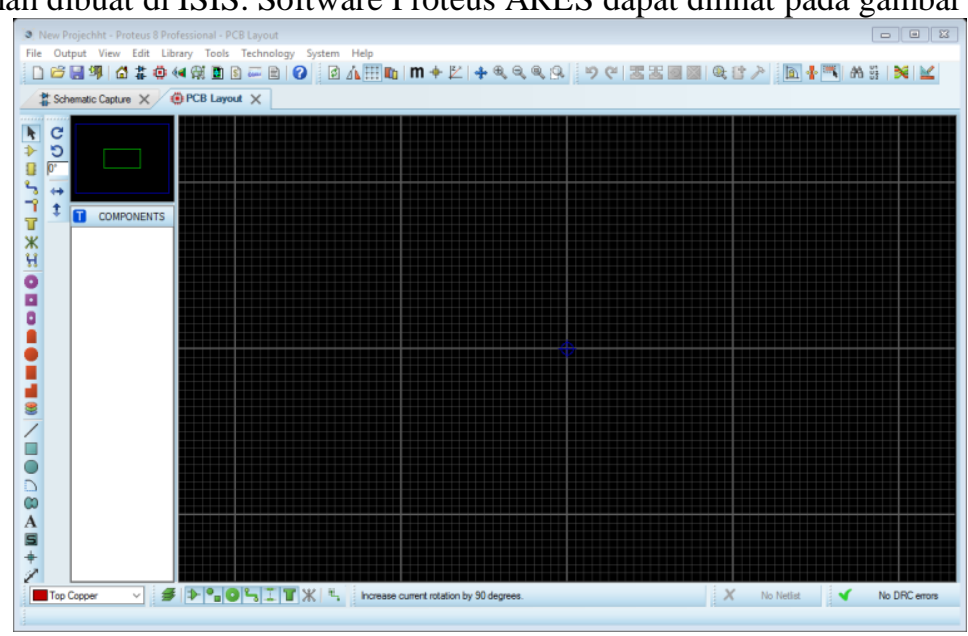

Gambar 3. Tampilan Software Proteus AREUS

Untuk menjalankan system juga terdapat lima perangkat keras yaitu Motor DC, Driver Motor, Sensor Berat Load Cell, Driver HX711 dan juga Modul Sim800L. IC L298N merupakan module driver motor DC yang paling banyak digunakan atau dipakai di dunia elektronika yang difungsikan untuk mengontrol kecepatan serta arah perputaran motor DC. IC L298 merupakan sebuah IC tipe H-bridge yang mampu mengendalikan bebanbeban induktif seperti relay, solenoid, motor DC dan motor stepper. Pada IC L298 terdiri dari transistortransistor logik (TTL) dengan gerbang nand yang berfungsi untuk memudahkan dalam menentukan arah putaran suatu motor de maupun motor stepper. Untuk dipasaran sudah terdapat modul driver motor menggunakan ic 1298 ini, sehingga lebih praktis dalam penggunaannya karena pin I/O nya sudah terpackage dengan rapi dan mudah digunakan. Kelebihan akan modul driver motor L298N ini yaitu dalam hal kepresisian dalam mengontrol motor sehingga motor lebih mudah untuk dikontrol. Load cell adalah komponen utama pada sistem timbangan digital.

Tingkat keakurasian timbangan bergantung dari jenis load cell yang dipakai. Sensor load cell apabila diberi beban pada inti besi maka nilai resistansi di strain gauge-nya akan berubah yang dikeluarkan melalui tiga buah kabel. Dua kabel sebagai eksitasi dan satu kabelnya lagi sebagai sinyal keluaran ke kontrolnya. Sebuah load cell terdiri dari konduktor, strain gauge, dan wheatstone bridge. Load Cell memiliki respon osilasi yang membutuhkan waktu untuk menetap terlebih dahulu sebelum digunakan. Pengukuran dinamis mengacu pada penentuan nilai akhir dari sinyal sensor sedangkan outputnya masih dalam osilasi. Oleh karena itu, Menentukan nilai dari ukur dalam waktu tercepat mungkin sangat diperlukan untuk mempercepat proses pengukuran, yang mana sangat penting terutama dalam beberapa petanian. Salah satu contoh pengolahan yang dapat dilakukan pada sinyal output sensor adalah pengkalibrasian untuk mencapai koreksi respon yang paling akurat. Implementasi perancangan perangkap terbagi atas tiga bagian, yaitu konstruksi perangkap, perangkat pendukung, dan hasil akhir alat. 
1. Konstruksi Perangkap

Implementasi konstruksi perangkap terbagi atas empat bagian, yaitu implementasi kerangka badan perangkapt, implementasi penampung perangkap, implementasi dinding geser perangkap, dan implementasi penimbang target.

2. Kerangka Badan Perangkap

Implementasi kerangka badan perangkap menggunakan bahan material acrylic. Acrylic yang digunakan memiliki ketebalan $3 \mathrm{~mm}$. Alasan menggunakan material acrylic adalah karena mudah dibentuk, tidak mudah pecah, ringan, dan elastis. Bahan dan peralatan yang digunakan untuk membuat kerangka alat, yaitu gerinda, bor duduk, glue gun, cutter, pipa, baut dan mur.

3. Kerangka perangkap dibuat berbentuk dua bangun ruang persegi panjang dan persegi yang digabungkan.

Tahap pengerjaannya terdiri dari beberapa tahap.

4. Penampung Perangkap

Implementasi penampung perangkap menggunakan bahan material acrylic sebagai rangka dan sebagai dinding, acrylic digunakan karena kuat dan ringan sehingga tidak menambah berat dari perangkap.

5. Dinding Geser Perangkap

Implementasi dinding geser perangkap menggunakan modifikasi dari beberapa plat besi. Plat besi kemudian ditempel pada plat acrylic sehingga menjadi dinding yang bisa menggeser secara otomatis dengan lebih dahulu diprogram melalui mikrokontroler yang disambungkan dengan driver L298.

6. Perancangan Penimbang Target

Implementasi perancangan penimbang target dilakukan dengan tetap menggunakan papan plat acrylic. Alasan menggunakan acrylic dikarenakan materialnya yang ringan dan lentur sehingga bisa kuat menahan beban dari hewan yang masuk kedalam perangkap.

7. Perangkat Pendukung

Implementasi perangkat pendukung terbagi atas tiga bagian yaitu rangkaian elektronika, mikrokontroler ATMEGA328 Arduino Uno, dan program mikrokontroler arduino.

Implementasi program mikrokontroler arduino dibuat menggunakan bahasa pemograman C. Software yang digunakan untuk membuat program adalah editor dan compiler Arduino. File program berekstensi *.ino file yang sudah dikompilasi akan di upload kedalam mikrokontroler arduino. Program mikrokontroler arduino dapat dilihat pada gambar 4.

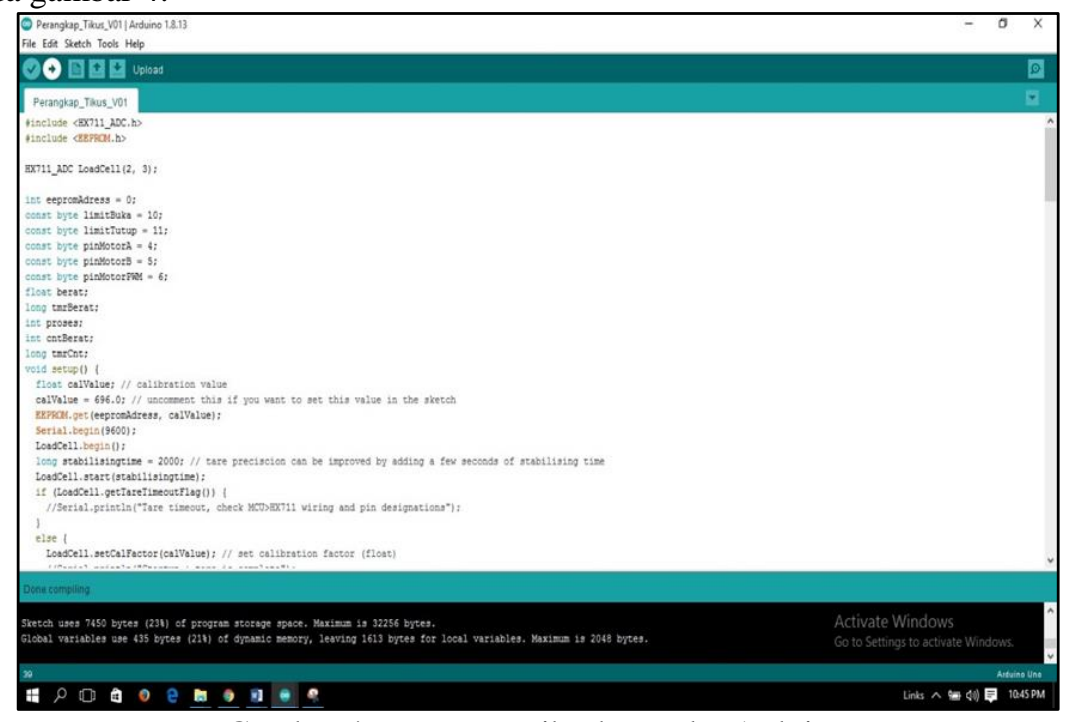

Gambar 4. Program Mikrokontroler Arduino

Setelah melakukan semua tahap implementasi maka semua hasilnya disatukan dan dijadikan hasil akhir dari alat yang akan diuji terlebih dahulu dan akhirnya akan siap untuk digunakan. Tampilan akhir dan skema perangkap hewan otomatis dapat dilihat pada gambar 5 . 


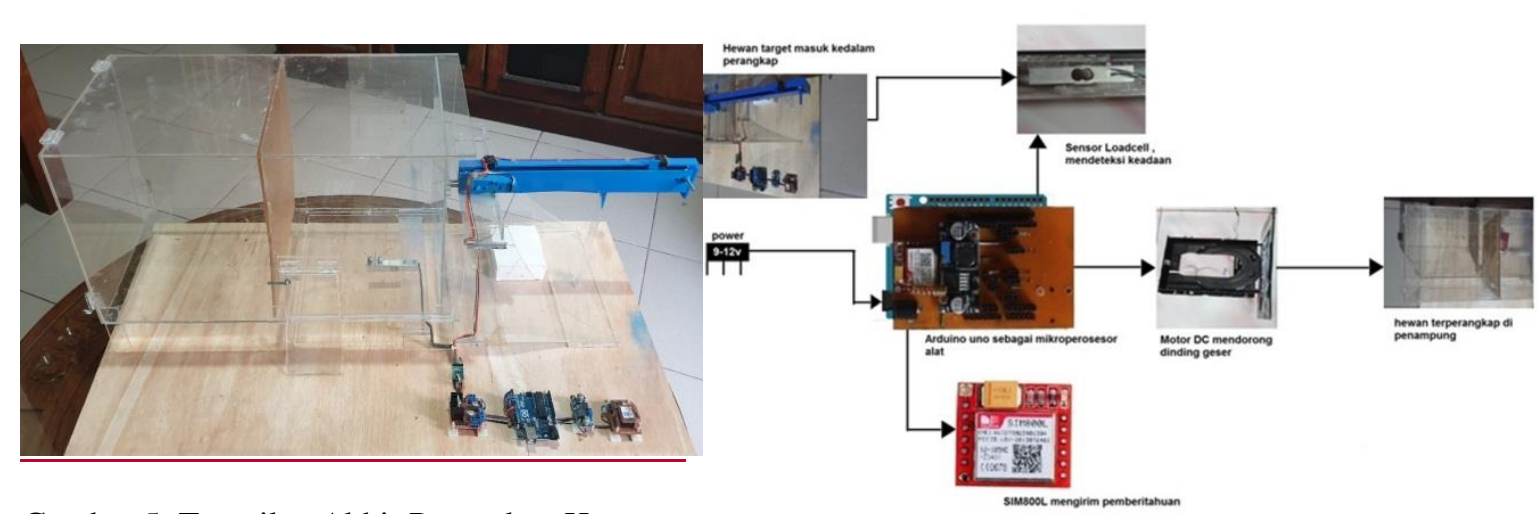

Gambar 5. Tampilan Akhir Perangkap Hewan Otomatis

Gambar 6. Skema Perangkap Hewan Otomatis

\section{Kesimpulan}

Kesimpulan dari penelitian :

1. Sistem dapat menambah efektivitas waktu dari petani dengan meminimalisir kegiatan yang dibutuhkan dengan alat ini.

2. Semua sensor dapat bekerja dengan baik dalam menyampaikan data ke mikrokontroler.

3. Informasi berhasil dikirim ke petani dengan menggunakan modul SIM800L.

\section{Daftar Pustaka}

[1] D. Satria, Z. Zainal, and T. Hidayat, "Plant Watering System Based on the Internet of Thing," J. Nas. Komputasi dan Teknol. Inf., vol. 1, no. 1, 2018.

[2] M. S. Anita Sindar, "Machine Learning Prediksi Karakter Pengguna Hastag (\#) Bahasa Generasi Milenial Di Sosial Media."

[3] C. Chotimah and K. P. Kartika, "Sistem Penyiraman Dan Pengusir Hama Otomatis Pada Daun Mint Berbasis Mikrokontroler Arduino Uno,” Antivirus J. Ilm. Tek. Inform., vol. 13, no. 1, pp. 36-47, 2019.

[4] Dicky P; Dendy PN; Henri P, “Altekno-Denhawer : Alat Teknologi Pendeteksi Dan,” J. Sci. Pinisi, vol. 3, no. 2, pp. 93-97, 2017.

[5] K. S. Kaswan, S. P. Singh, and S. Sagar, "Role of Arduino in real world applications," Int. J. Sci. Technol. Res., vol. 9, no. 1, pp. 1113-1116, 2020.

[6] A. Septiawan and Subandi, "Alat Perangkap Serangga Menggunakan Tegangan Kejut Untuk Pengendalian Hama Pertanian," Semin. Nas. ITENAS, pp. 19-24, 2018.

[7] D. A. Siregar and Hambali, "Alat Pembasmi Hama Tanaman Padi Otomatis Berbasis Mikrokontroler Menggunakan Tegangan Kejut Listrik,” JTEIN J. Tek. Elektro Indones., vol. 1, no. 2, pp. 55-62, 2020.

[8] M. Zikri and R. Khair, "Rancang Bangun Monitoring Parkir Berbasis Arduino," Teknovasi, vol. 05, no. 1, pp. 27-38, 2018. 